\title{
The Impact of Faculty Development Activities on Engineering Faculty Teaching Practices
}

\author{
Catherine E. Brawner, Richard M. Felder, \\ Rodney H. Allen, and Rebecca Brent \\ Research Triangle Educational Consultants/ \\ COMP-AID/North Carolina State University
}

\begin{abstract}
The SUCCEED (Southeastern University and College Coalition for Engineering EDucation) faculty development team has spent several years helping engineering faculty members learn and implement instructional techniques that have been proven effective by research and experience. As part of the assessment effort, SUCCEED fielded e-mail surveys in 1997 and 1999 to which respondents reported their use of such instructional practices as writing formal instructional objectives for undergraduate classes, conducting in-class learning activities, and assigning teambased homework in traditional lecture courses (in contrast with laboratory and design courses, where teams have traditionally been used). About a third of surveyed faculty members returned the survey in each administration (32\% in 1997 and 36\% in 1999).
\end{abstract}

This paper compares the results of the two surveys with respect to the use of certain teaching practices among faculty and shows the relationship between attending faculty development activities focused on teaching and the use of non-traditional teaching methods. The results indicate that attending more teaching workshops is associated with greater use of active and cooperative learning in traditional lecture classes.

\section{Introduction}

SUCCEED (Southeastern University and College Coalition for Engineering EDucation) is a National Science Foundation-sponsored engineering education coalition. SUCCEED was first funded in 1992 and has spent the past four years scaling up and institutionalizing many of the educational reforms developed and pilot-tested in its first five years of funding. A major component of this effort is the design and implementation of a faculty development program. The program objectives are (1) to promote faculty adoption of non-traditional instructional methods and materials that have been proven effective by classroom research studies and (2) to improve institutional support for teaching at each of the eight SUCCEED campuses. ${ }^{1}$

To assess the impact of faculty development activities on the SUCCEED member campuses, all engineering faculty members were sent a baseline campus climate survey in the 1997-1998 academic year and a second survey in 1999-2000. (A third survey is planned for 2001-2002). The surveys asked respondents to answer questions about their teaching experiences and practices. Among other things, they were asked about their prior involvement with faculty

Proceedings of the 2001 American Society for Engineering Education Annual Conference \& Exposition Copyright (C) 2001, American Society of Engineering Education 
development programs (e.g., attending workshops or seminars dedicated to teaching improvement) and their frequency of use of various instructional techniques. In this paper, we briefly describe the survey methodology and respondent profile for the two survey periods and then summarize the principal survey results.

\section{Methodology}

The 1997 survey was sent to 1550 faculty members at the eight campuses who had e-mail addresses and the 1999 survey was sent to 1600 faculty members. The samples encompass virtually all engineering faculty, including full time, adjunct, visiting, and others with faculty status. Most 1997 surveys and all 1999 surveys were sent by e-mail in the late fall of the given year and followed up in the early spring of the following year. A few 1997 surveys were administered on the World Wide Web as an experiment. ${ }^{2}$

The survey response rates were $32 \%$ in 1997 and $36 \%$ in 1999. Individual campus response rates ranged from $26 \%$ to $45 \%$ in 1997 and from $28 \%$ to $47 \%$ in 1999. The response rates at each institution were roughly equal in both years except for one institution, where the rate nearly doubled due to an improved survey collection methodology.

Data from both surveys were analyzed using standard statistical methods. Responses were tested to determine if there were any significant differences among categories of respondents and over time. An alpha level of 0.05 was set for all tests of statistical significance.

In 1999, but not in 1997, respondents were asked if they had taught an undergraduate course in the past three years. If they had not, they were asked only to answer demographic questions. Seventy-five people (13\%) were thereby eliminated from most of the analysis. Some questions were slightly altered between administrations but the changes should not impact the conclusions to be drawn from them.

\section{Findings}

\subsection{Respondent Profile}

In both years, approximately three-fourths of the respondents identified themselves as teaching/research faculty with the balance either teaching only, research only, or administrators. In both cases, the percentage of full professors responding was about $42 \%$. Responses from assistant professors increased from $19 \%$ to $21 \%$ while associate professor responses decreased from $32 \%$ to $27 \%$. The remaining respondents were instructors, lecturers, adjuncts, or some other rank. Approximately $90 \%$ of the respondents were male. The mean years of faculty service in 1999 was 15, 12 at the current institution. An overwhelming majority (>90\%) had heard of the SUCCEED coalition or participated in one or more of its programs, likely overstating the familiarity with SUCCEED among the faculty population at large.

Table 1 shows the number of teaching seminars, workshops, and conferences attended by the respondents in their careers and the number attended during the previous academic year. In 1999,

Proceedings of the 2001 American Society for Engineering Education Annual Conference \& Exposition Copyright (C) 2001, American Society of Engineering Education 
only those respondents who had taught in the prior three years were asked this question while in 1997 all respondents answered it. This difference may account in part for the higher percentages of respondents in 1999 who attended workshops in the prior academic year.

Table 1: Attendance at teaching seminars, workshops, or conferences

\begin{tabular}{|c|c|c|c|c|c|}
\hline \multirow{2}{*}{$\begin{array}{l}\text { \# of teaching } \\
\text { seminars }\end{array}$} & \multicolumn{2}{|c|}{ Career } & \multirow{2}{*}{$\begin{array}{l}\text { \# of teaching } \\
\text { seminars }\end{array}$} & \multicolumn{2}{|c|}{ Prior academic year } \\
\hline & $\underline{1997}$ & $\underline{1999}$ & & $\underline{1997}$ & $\underline{1999}$ \\
\hline None & $15 \%$ & $10 \%$ & None & $44 \%$ & $41 \%$ \\
\hline $1-2$ & $26 \%$ & $21 \%$ & 1 & $30 \%$ & $23 \%$ \\
\hline $3-5$ & $29 \%$ & $31 \%$ & 2 & $16 \%$ & $20 \%$ \\
\hline $6-10$ & $16 \%$ & $16 \%$ & $\geq 3$ & $9 \%$ & $17 \%$ \\
\hline$>10$ & $13 \%$ & $23 \%$ & & & \\
\hline $\mathrm{n}$ & 497 & 510 & $\mathrm{n}$ & 496 & 509 \\
\hline \multicolumn{3}{|c|}{$\begin{array}{l}\text { Since you began teaching, about how many seminars, } \\
\text { workshops, conferences, etc., have you attended that } \\
\text { were specifically related to teaching? }\end{array}$} & \multicolumn{3}{|c|}{$\begin{array}{l}\text { From September } 1996 \text { [August 1998] through August } \\
1997 \text { [July 1999], how many seminars, workshops, } \\
\text { conferences, etc., did you attend that were specifically } \\
\text { related to teaching? }\end{array}$} \\
\hline
\end{tabular}

Younger faculty members are more likely to have attended a teaching seminar in the past year than their full professor counterparts. Participation has increased for assistant and associate professors while holding relatively constant for full professors. Those who did attend teaching seminars the prior year attended more in 1999 than they did in 1997. The number of career teaching seminars has increased as well for all ranks, as shown in tables 2 and 3.

Table 2: Teaching seminars attended past year

\begin{tabular}{|l|c|c||c|c||c|c|}
\hline \multirow{2}{*}{} & \multicolumn{7}{|c|}{ Rank and Year } \\
\cline { 2 - 5 } & Assistant 97 & $\underline{\text { Assistant 99 }}$ & Associate 97 & $\underline{\text { Associate 99 }}$ & Professor 97 & Professor 99 \\
\hline 0 & $35 \%$ & $30 \%$ & $45 \%$ & $38 \%$ & $47 \%$ & $46 \%$ \\
\hline 1 & $32 \%$ & $23 \%$ & $30 \%$ & $26 \%$ & $30 \%$ & $22 \%$ \\
\hline 2 & $18 \%$ & $24 \%$ & $17 \%$ & $22 \%$ & $15 \%$ & $16 \%$ \\
\hline $3+$ & $15 \%$ & $23 \%$ & $8 \%$ & $14 \%$ & $8 \%$ & $16 \%$ \\
\hline
\end{tabular}

Table 3: Career teaching seminars

\begin{tabular}{|l|c|c||c|c||c|c|}
\hline \multirow{2}{*}{} & \multicolumn{7}{|c|}{ Rank and Year } \\
\cline { 2 - 7 } & Assistant 97 & Assistant 99 & Associate 97 & Associate 99 & Professor 97 & Professor 99 \\
\hline 0 & $19 \%$ & $11 \%$ & $9 \%$ & $6 \%$ & $15 \%$ & $10 \%$ \\
\hline $1-2$ & $32 \%$ & $30 \%$ & $28 \%$ & $15 \%$ & $21 \%$ & $21 \%$ \\
\hline $3-5$ & $35 \%$ & $36 \%$ & $31 \%$ & $37 \%$ & $27 \%$ & $25 \%$ \\
\hline $6-10$ & $8 \%$ & $11 \%$ & $21 \%$ & $23 \%$ & $18 \%$ & $14 \%$ \\
\hline$>10$ & $6 \%$ & $13 \%$ & $11 \%$ & $20 \%$ & $19 \%$ & $30 \%$ \\
\hline
\end{tabular}




\subsection{Lecturing for most of every class period}

Instructor-centered teaching methods, particularly lecturing, require little active student involvement. As can be seen in Table 4, the percent of faculty lecturing for most of the class period every class, has gone down slightly but significantly $(\mathrm{p}=.018)$.

Table 4: Frequency of lecturing for most of a class period

\begin{tabular}{|l|c|c|}
\hline & 1997 & 1999 \\
\hline Every class & $66 \%$ & $59 \%$ \\
\hline Once or more/week & $29 \%$ & $33 \%$ \\
\hline Once or more/month & $3 \%$ & $5 \%$ \\
\hline Once or more/semester & $1 \%$ & $<1 \%$ \\
\hline Never & $1 \%$ & $2 \%$ \\
\hline $\mathrm{N}$ & 468 & 509 \\
\hline
\end{tabular}

Many SUCCEED effective teaching seminars, as well as others on the the topic, encourage faculty members to incorporate group work and other learner-centered activities into the class period in lieu of straight lecturing. The survey results show that this emphasis appears to be having the desired effect. Attending teaching seminars, both during the past year and over the course of one's career is significantly associated with a decreased frequency of lecturing for most of every class period. In 1997, the Spearman correlation ( $\rho$ ) between lecturing every class period and career teaching seminars attended was -.211 , in $1999 \rho$ was -.202 . Both correlations are significant at the $\alpha=.001$ level. Similar but lower correlations exist for the relationship between teaching seminars attended in the past year and lecturing for most of every class period. Figure 1 shows the relationship between the number of teaching seminars attended in one's career and lecturing for most of every class period.

Figure 1: Percent lecturing for most of every class period

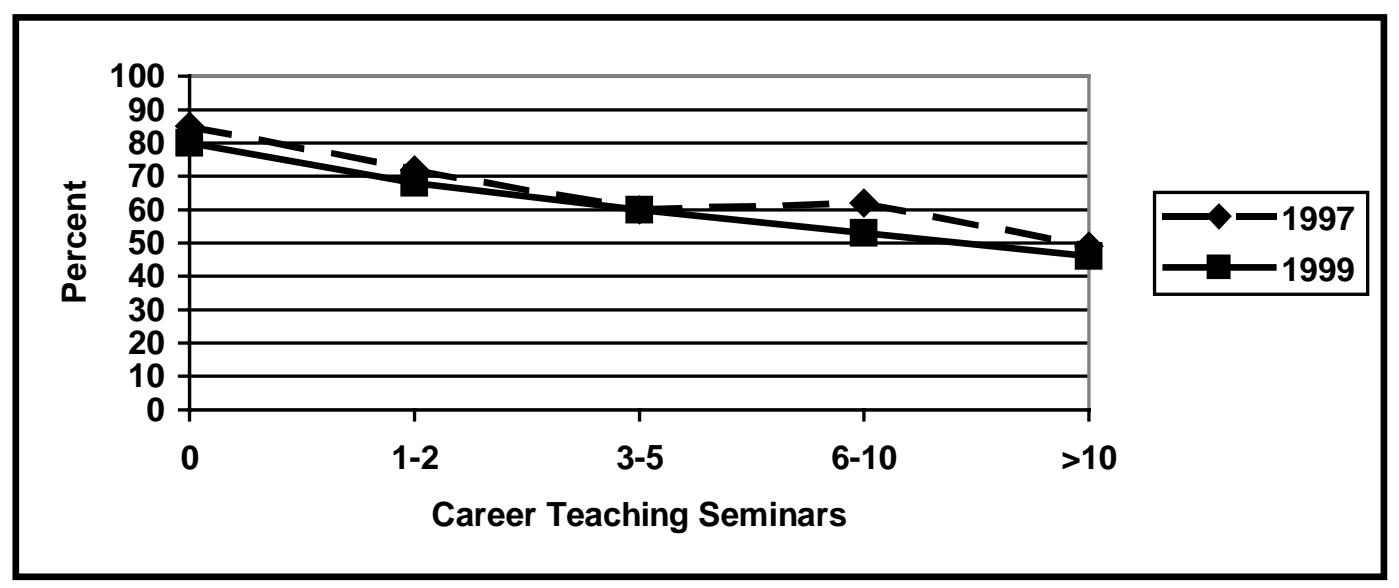

Proceedings of the 2001 American Society for Engineering Education Annual Conference \& Exposition Copyright ${ }^{\circ}$ 2001, American Society of Engineering Education 


\subsection{Active Learning}

Faculty members were asked how often they put students into pairs or small groups to answer questions or solve problems for brief intervals during class and how often they did so for most of a class period. Table 5 summarizes their responses.

It is important to recall that the 1997 survey was taken in the fifth year of the SUCCEED Coalition, when many faculty members had already participated in the teaching effectiveness workshops that had been presented at most of the Coalition campuses throughout the preceding five years. Although the percentage of faculty members using active learning did not change significantly in the two years between surveys, it is encouraging that so many of the respondents in both years reported using this non-traditional technique at all.

Table 5: Use of active learning in class

\begin{tabular}{|l|c|c|c|c|}
\hline \multirow{2}{*}{} & \multicolumn{2}{|c|}{$\begin{array}{c}\text { Put students in groups } \\
\text { for brief intervals }\end{array}$} & \multicolumn{2}{c|}{$\begin{array}{c}\text { Put students in groups } \\
\text { for most of class }\end{array}$} \\
\cline { 2 - 5 } & 1997 & $\underline{1999}$ & $\underline{1997}$ & $\underline{1999}$ \\
\hline Every class & $3 \%$ & $6 \%$ & $1 \%$ & $2 \%$ \\
\hline Once or more/week & $14 \%$ & $16 \%$ & $6 \%$ & $6 \%$ \\
\hline Once or more/month & $23 \%$ & $18 \%$ & $12 \%$ & $12 \%$ \\
\hline Once or more/semester & $18 \%$ & $20 \%$ & $21 \%$ & $17 \%$ \\
\hline Never & $42 \%$ & $40 \%$ & $60 \%$ & $62 \%$ \\
\hline $\mathrm{N}$ & 464 & 509 & 466 & 505 \\
\hline
\end{tabular}

Attending more teaching seminars, particularly during the previous year, is associated with using active learning in class, as shown in figure 2. The strength of the correlation ranges from $\rho=$ .123 for the relationship between career teaching seminars and putting students into groups for most of class to $\rho=.270$ for the relationship between teaching seminars attended last year and putting students into groups for brief intervals during the class period as the correlation matrix in table 6 shows. The slight and insignificant decrease in percentages of the high attendance group using active learning from 1997 to 1999 may reflect an increased willingness of faculty members not already committed to these non-traditional methods to attend teaching workshops. 
Figure 2: Put students in groups in class during the semester

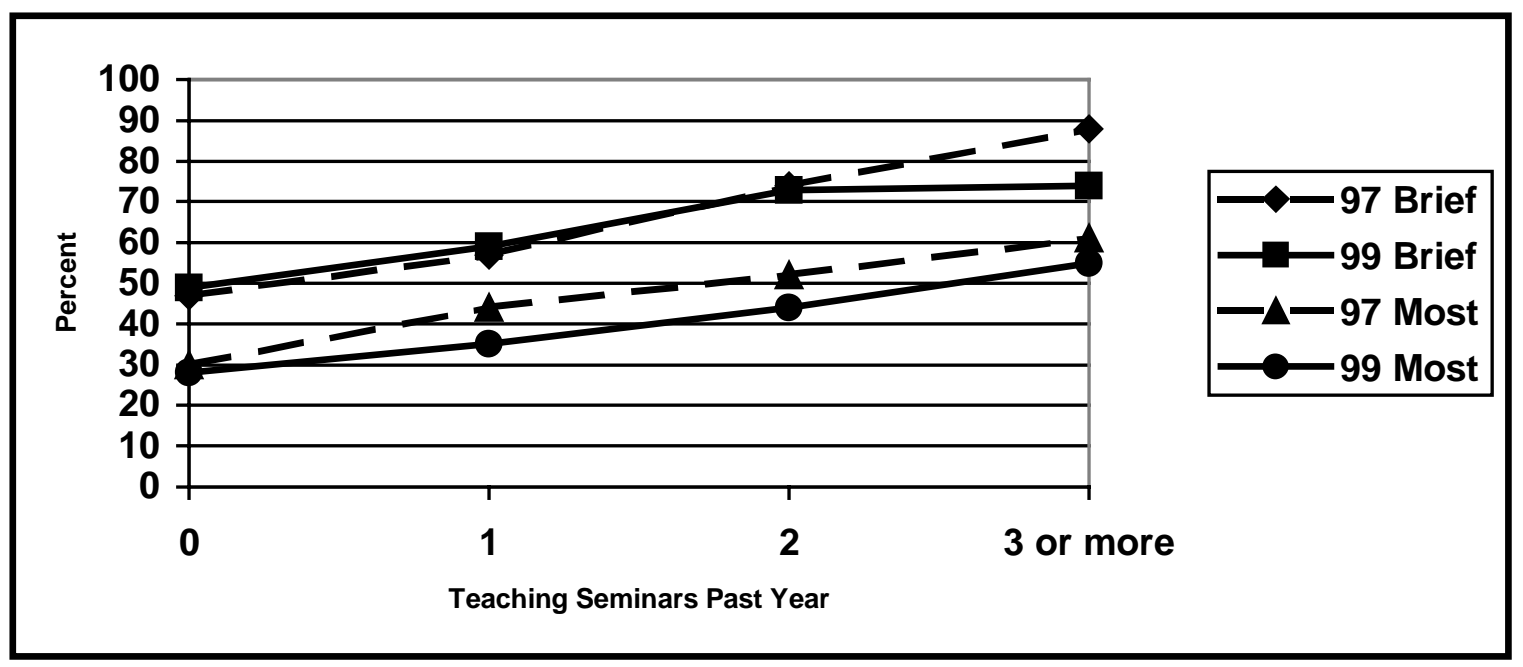

Table 6 Correlation matrix for use of active learning in class

\begin{tabular}{|l|c|c|}
\hline & $\begin{array}{l}\text { Put students into groups } \\
\text { for brief intervals }\end{array}$ & $\begin{array}{l}\text { Put students into groups } \\
\text { for most of class }\end{array}$ \\
\hline 97 teaching seminars last year & $.270 * * * * * 197 * * * *$ \\
\hline 97 career teaching seminars & $.292 * * * * *$ & $.174 * * * * *$ \\
\hline 99 teaching seminars last year & $.259 * * * * *$ & $.208 * * * * *$ \\
\hline 99 career teaching seminars & $.168 * * * * *$ & $.123 * * * *$ \\
\hline
\end{tabular}

$* * * * * \mathrm{p}<.0005 . * * * * \mathrm{p}<.001$

\subsection{Assignments and cooperative learning}

Faculty members were asked how often they assigned homework to individuals, how often they permitted students to work in groups, and how often they required students to work in groups to complete assignments. Table 7 shows the results. Faculty members in 1999 allowed and required students to do homework in teams significantly more often than in 1997 ( $p<.0005)$. There was no significant difference between the two groups in how often they assigned homework to individuals. 
Table 7: Assignments

\begin{tabular}{|l|c|c|c|c|c|c|}
\hline \multirow{2}{*}{} & \multicolumn{2}{|c|}{ Individual Homework } & \multicolumn{2}{|c|}{ Team option } & \multicolumn{2}{c|}{ Team required } \\
\cline { 2 - 7 } & $\underline{1997}$ & $\underline{1999}$ & $\underline{1997}$ & $\underline{1999}$ & $\underline{1997}$ & $\underline{1999}$ \\
\hline Once or more/week & $55 \%$ & $67 \%$ & $24 \%$ & $35 \%$ & $10 \%$ & $16 \%$ \\
\hline Once or more/month & $32 \%$ & $18 \%$ & $17 \%$ & $20 \%$ & $10 \%$ & $13 \%$ \\
\hline Once or more/semester & $7 \%$ & $7 \%$ & $24 \%$ & $17 \%$ & $25 \%$ & $25 \%$ \\
\hline Never & $7 \%$ & $8 \%$ & $34 \%$ & $26 \%$ & $55 \%$ & $46 \%$ \\
\hline $\mathrm{N}$ & 472 & 508 & 454 & 504 & 465 & 507 \\
\hline
\end{tabular}

The percentages of faculty requiring students to work together on assignments increased over the survey period and is associated with attending more teaching workshops $\left(\rho_{97}=.121, p<.05 ; \rho_{99}\right.$ $=.127, \mathrm{p}<.01$ ), particularly the first ones after which use of group work levels off. Requiring students to learn from each other by doing homework together is an area of emphasis in many effective teaching seminars including those offered by SUCCEED. Figure 3 shows the relationship between career teaching seminars and requiring students to work together on homework.

Figure 3: Require group work for homework completion

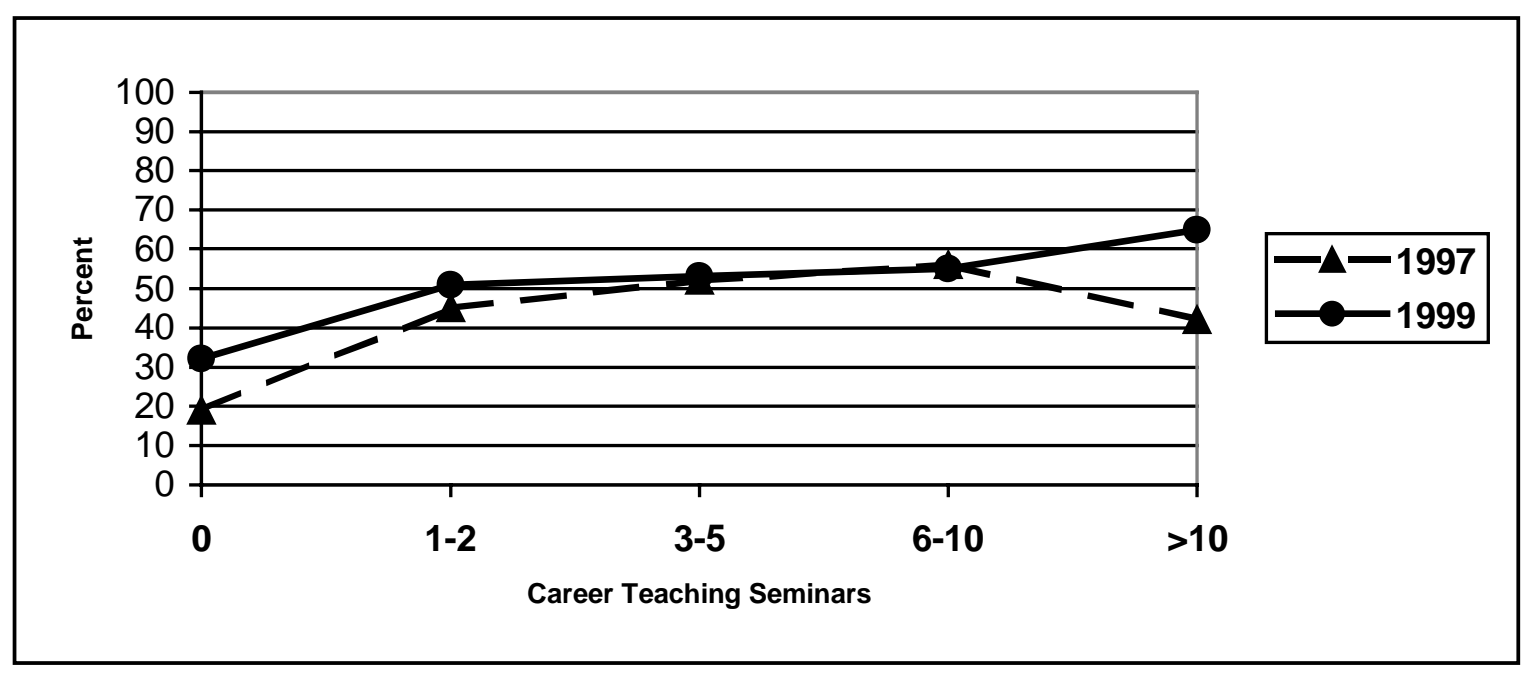

\subsection{Writing instructional objectives and giving study guides to students}

Writing formal instructional objectives that state explicitly what students should be able to do after completing segments of a course has a positive impact on both the level and quality of learning ${ }^{3}$ and are areas emphasized in SUCCEED teaching workshops. Respondents were asked how often they write instructional objectives for their courses and how often they gave their students explicit indications of what they (the students) should be able to do to demonstrate their

Proceedings of the 2001 American Society for Engineering Education Annual Conference \& Exposition Copyright (C) 2001, American Society of Engineering Education 
mastery of course material. In 1997, respondents were asked how often they gave students study guides before both tests and exams while in 1999 the two questions were collapsed into one. Table 8 shows the how often faculty members write instructional objectives and give their students study guides before tests and exams. The 1997 responses were averaged into one variable here.

Table 8: Write instructional objectives and provide study guides to students

\begin{tabular}{|l|c|c|c|c|}
\hline \multirow{2}{*}{} & \multicolumn{2}{|c|}{ Instructional objectives } & \multicolumn{2}{c|}{ Provide study guides } \\
\cline { 2 - 5 } & 1997 & 1999 & 1997 & 1999 \\
\hline Always & $39 \%$ & $43 \%$ & $39 \%$ & $36 \%$ \\
\hline Usually & $21 \%$ & $23 \%$ & $24 \%$ & $25 \%$ \\
\hline Sometimes & $21 \%$ & $23 \%$ & $18 \%$ & $20 \%$ \\
\hline Never & $19 \%$ & $12 \%$ & $19 \%$ & $20 \%$ \\
\hline $\mathrm{n}$ & 497 & 502 & 494 & 499 \\
\hline
\end{tabular}

There is a slightly positive correlation between the number of teaching seminars attended in the previous year and whether a faculty member writes instructional objectives in their courses ( $\rho_{97}=$ $\left..133, \mathrm{p}=.005 ; \rho_{99}=.096, \mathrm{p}<.05\right)$. Although these correlations are small, and not significant for career teaching seminars attended, a gratifyingly large number of faculty members do write instructional objectives for their courses and the percentage doing so has increased significantly between 1997 and 1999 ( $\mathrm{p}=.025)$.

Figure 4: Always or usually write instructional objectives

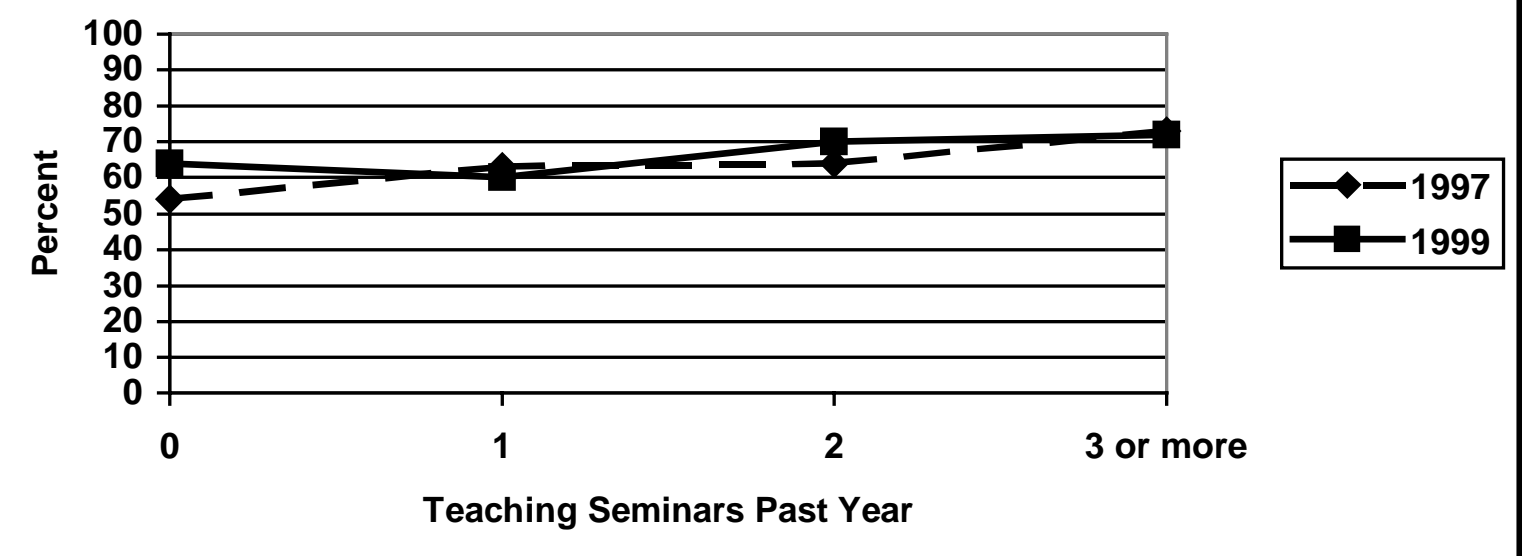

\subsection{Impact of teaching seminars}

In 1999, faculty members were asked whether they had changed their teaching behavior as $a$ result of attending education related seminars, workshops and conferences over the past three years. Sixty percent indicated that they use more active learning in class and over $40 \%$ indicated

Proceedings of the 2001 American Society for Engineering Education Annual Conference \& Exposition Copyright (C) 2001, American Society of Engineering Education 
that they use more team-based learning for assignments and write instructional objectives for their classes. Figure 5 shows that attending more teaching seminars reinforces faculty behavior with respect to writing instructional objectives, increased use of active learning, and team-based assignments.

Figure 5: Use of student-centered teaching methods as a function of attending teaching seminars

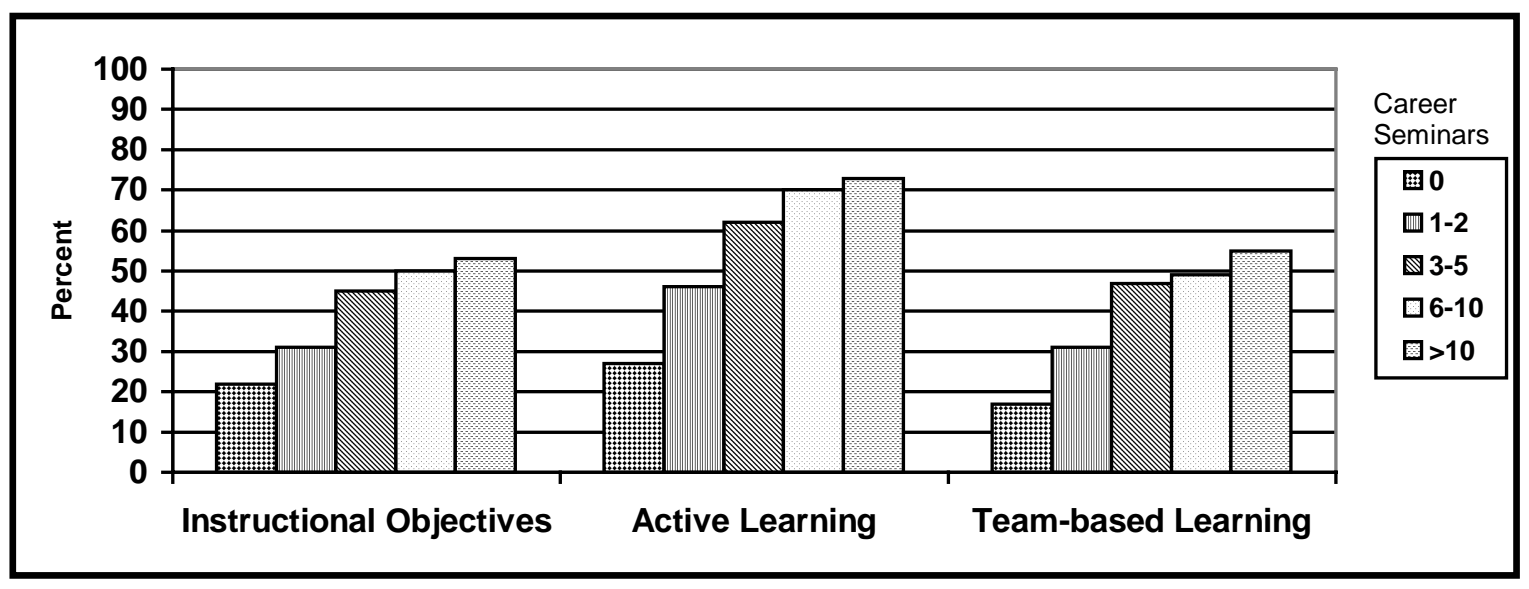

\section{Discussion and conclusions}

As noted in the introduction, a goal of the SUCCEED Coalition Faculty Development Program is to promote the use of alternative instructional methods that have been proven effective. The purpose of the two surveys reported in this study was to assess the extent to which engineering faculty in the SUCCEED Coalition are using these methods and to determine whether and how the percentage of faculty using them is changing over time. It is almost impossible to determine the magnitudes of these changes with confidence, however, since the sample populations were different in both years (for example, the 1999 survey excluded respondents who had not taught in the preceding three years). We also need to allow for the probability that faculty who use the alternative practices advocated by SUCCEED are more likely to respond to surveys of this nature than faculty who are strictly traditional in their teaching practices and therefore many of the percentages reported are higher than would be expected for the faculty at large.

However, even with these caveats, we may draw the following inferences from the survey results:

1. A significant percentage of engineering faculty at SUCCEED institutions has participated in teaching workshops and seminars. Of the respondents in the latest survey, $90 \%$ had done so in their careers and roughly $60 \%$ had done so in the prior academic year. Even if we assume that non-respondents were less likely to attend a teaching workshop than respondents, the percentage of all faculty attending these workshops is still sufficiently high for SUCCEED to reach one of its major milestones that $60 \%$ of all faculty attend some faculty development activity.

Proceedings of the 2001 American Society for Engineering Education Annual Conference \& Exposition Copyright (C) 2001, American Society of Engineering Education 
2. A gratifyingly large number of the engineering faculty use the active and team-based instructional methods being promoted by the Coalition Faculty Development Program. Sixty percent of the 1999 respondents used active learning in their lecture classes for brief intervals and $40 \%$ occasionally did so for entire class periods, $74 \%$ allowed groupwork in assignments, and $54 \%$ required it.

3. Indications are that faculty development workshops and seminars played a major role in faculty's use of alternative instructional methods. The likelihood of faculty using these techniques increased with the number of workshops they had attended, and substantial numbers of respondents stated that the changes in their teaching practices came about as a result of their attendance.

4. The percentage use of the given techniques between 1997 and 1999 did change significantly in some cases even if the change was modest. In the case of significant changes, the direction was in the direction advocated by SUCCEED (i.e. less lecturing every class period and more group work).

An additional speculative conclusion is that the impact of Coalition faculty development activities on faculty teaching practices may be greater than the survey results indicate. The 1997 survey was conducted in the fifth year of the Coalition's existence, so that the survey respondents already had several opportunities to participate in teaching workshops and many had done so. The most receptive faculty to proposed changes in teaching practices would probably have been among the early workshop attenders; two of the authors (Felder and Brent) gave most of the workshops in the first five years of SUCCEED and can attest to the fact that the level of use of student-centered instructional methods in the first year of the Coalition was well below the level reported in the fifth year survey. The difficulty of persuading additional traditional faculty members to change their practices should increase with time, which might account in part for the lack of significant measured change from 1997 to 1999.

The Coalition's primary faculty development function at this point is not so much to persuade traditional instructors to adopt new methods as to provide guidance and support to new faculty members and to experienced faculty members who have begun to make the changes. Workshops and learning communities that support these functions are in place on most of the SUCCEED campuses, but their effects may not be obvious from survey results for some time to come. However, we can be encouraged by the participation of younger faculty in these programs as a means to change the climate for teaching on our campuses in the long run.

1. The members of SUCCEED are: Clemson University, Florida A\&M University-Florida State University College of Engineering, Georgia Institute of Technology, North Carolina A\&T State University, North Carolina State University, University of Florida, University of North Carolina at Charlotte, and Virginia Polytechnic Institute and State University.

2. Brawner, C., Felder, R., Allen, R., Brent, R., and Miller, T. "A comparison of electronic surveying by e-mail and web." In Proceedings of the 2001 American Society of Engineering Education Conference. Albuquerque, NM, June 2001.

Proceedings of the 2001 American Society for Engineering Education Annual Conference \& Exposition Copyright $\odot$ 2001, American Society of Engineering Education 
3. See for example: Johnson, D., Johnson, R., and Smith, K. Active learning: Cooperation in the college classroom, Edina, MN: Interaction Book Co., 1998.

\section{CATHERINE E. BRAWNER}

Catherine E. Brawner is president of Research Triangle Educational Consultants. She specializes in evaluation of distance education, educational innovation, and technology use in the classroom. She is the principal evaluator of the SUCCEED Coalition.

\section{RICHARD FELDER}

Richard Felder is Hoechst Celanese Professor Emeritus of Chemical Engineering at North Carolina State University and Faculty Development Codirector of the NSF-sponsored SUCCEED Coalition. He is a Fellow Member of the ASEE, and codirector of the National Effective Teaching Institute.

\section{RODNEY H. ALLEN}

Rod Allen is a research scientist and independent computer consultant. His company, COMP-AID, specializes in innovative applications, crisis consulting, e-commerce, Internet, computer aided design,computer graphics, efficient computing, and teaching computer courses, short courses, and seminars.

\section{REBECCA BRENT}

Rebecca Brent is an educational consultant on the staff of the College of Engineering at North Carolina State University, Faculty Development Codirector of the SUCCEED Coalition, Adjunct Professor of Education at East Carolina University, and codirector of the National Effective Teaching Institute. 